\title{
CROWN, NOBILITY AND INDUSTRY IN EIGHTEENTH-CENTURY SPAIN
}

In eighteenth-century Spain the encouragement of commerce and industry occupied an important place in the plans of the Bourbons for reviving national strength after the great crisis of the seventeenth century. Successive royal administrations resorted to a formidable array of measures designed to stimulate economic development. Government policy was directed primarily to furnishing commerce and industry with material assistance: subsidies, tax exemptions, protective tariffs, etc. The crown was also concerned, however, with the deleterious effects upon economic progress of an apparently pervasive and tenacious system of values which looked upon manual labor in an industrial context and economic enterprise in general as dishonorable for noble and commoner alike.

Attempts to raise the status of commerce and industry had not been unknown before the eighteenth century. It was only then, however, that gradually changing political, economic and intellectual conditions made a concerted attack upon entrenched prejudices possible. Although progress toward national recovery was slow and difficult, the development of an increasingly centralized and efficient state machine committed to industrial and commercial expansion as a source of national strength inevitably moved the crown to consider measures designed to remove the obstacle to economic progress created by widespread disdain for industrial and commercial enterprise. Economic progress itself, evident after 1730 , more noticeable after I 760 , promoted social mobility at the expense of the established hierarchical social order. The gradual development of a middle class in the kingdom's urban centers also served to undermine traditional social values to some extent. And, finally, the expanding influence of enlightened thought upon educated opinion made the problem of a concept of labor which was both a detriment to national prosperity and an offense against reason seem graver than ever. It was not accidental that the great crusade of the eighteenth century against the folly of ideas on honor and dishonor was begun by the learned Benedictine, Feijóo, the first great figure of the Spanish Enlighten- 
ment. ${ }^{1}$ After Feijóo, progressive writers denounced prejudices against commerce and industry with increasing frequency. ${ }^{2}$

Eighteenth-century students of the problem offered several explanations to account for the seemingly chronic aversion of the Spanish for commercial and industrial enterprise. For example, one of the leading ministers of Charles III, the Count of Campomanes, attributed contempt for manual labor in an industrial context to the nature of the Spanish legal system which had assimilated, in his view, the distinction made by Roman law between the servile and honorable arts. $^{3}$ A contemporary of Campomanes suggested that Spaniards avoided commercial and industrial occupations because the Jews and Moriscos had been prominent in both these areas of activity before their expulsion from the peninsula. ${ }^{4}$ Most writers, however, placed the blame squarely on the shoulders of the nobility, in the first instance, for having developed a code of honor which held that manual labor in the industrial arts and participation in commercial enterprises were incompatible with noble status, and, in the second, for having imposed its standard of conduct upon the rest of society.

This problem, of course, was neither new nor unique to Spain. As elsewhere in early modern Europe, the steady expansion of royal power had allowed Spanish monarchs to form standing armies and thereby deprive the nobility of the essential place which it had held in the power structure of feudal society. This profound alteration in the nobility's political position did not lead to a corresponding change in the standards of conduct formed during the period when the nobility was a privileged caste because it alone provided the monarch with the military strength he required. Social prestige continued to remain attached to the pursuits which the nobility judged compatible with the honor and dignity of the profession of arms. ${ }^{5}$

1 Luis Sánchez Agesta, El pensamiento político del despotismo ilustrado (Madrid, 1963), pp. $142-143$.

2 Some examples: Antonio Arteta y Monteseguro, Disertación sobre el aprecio y estimación que se debe hacer de las artes prácticas y de los que las ejercen con honradez, inteligencia y aplicación (Zaragoza, I781); Francisco de Bruna, Reflexiones sobre las artes mecánicas, in: Pedro Rodríguez de Campomanes, Apéndice a la educación popular (4 vols.; Madrid, 1775), vol. III, pp. 295-302; Antonio Capmany y Montpalau, Discurso económico-político en defensa del trabajo mecánico. . . (Madrid, 1778); Antonio de los Heros, Discurso sobre el comercio (Madrid, 1775); Antonio Javier Pérez y López, Discurso sobre la honra y deshonra legal (Madrid, 1781 ).

${ }^{3}$ Pedro Rodríguez de Campomanes, Discurso sobre la educación popular y su fomento (Madrid, 1775), p. 84.

4 Pedro Berindoaga, "Memoria a remediar los obstáculos que se oponen al progreso de las manufacturas de lana", in: Memorias de la Sociedad Económica de Amigos del País (5 vols.; Madrid, I 780-1 795), vol. III, p. 102.

${ }^{5}$ For the medieval origins of this problem in Spain see: Pedro de Corominas, El senti- 
Criticism of the nobility became an important feature of enlightened thought in eighteenth-century Spain, as in most other European states. ${ }^{1}$ Feijóo began the attack by reproaching the nobility for believing that blood alone was a sufficient justification for the maintenance of its privileges. ${ }^{2}$ During the reign of Charles III, criticism became particularly intense. Eugenio Larruga, secretary of the General Junta of Commerce, rebuked nobles for abandoning "the virtue and patriotism of their progenitors" in favor of "insensate luxury". ${ }^{3}$ And two harsher critics, both members of the Royal Economic Society of Madrid, accused the nobility of being "a multitude of insensates" for its attitude toward commerce and industry. ${ }^{4}$ There was a general awareness that historical conditions had endowed the nobility with a privileged social position, but there was agreement that the circumstances that once had justified this situation no longer existed, and that the nobility must rejustify its place within the structure of society by displaying an active concern for the general welfare. Feijóo's appeal to the nobility to regenerate itself through work and virtue was the first of many similar exhortations, most of which specifically demanded that nobles contribute to the encouragement of economic progress. ${ }^{5}$

The structure of the nobility during the eighteenth century was substantially the same as it had been in the sixteenth. It was numerous, comprising nearly 500,000 individuals out of a population of $10,000,000$ in 1787 , and it was divided by considerable social, economic and regional differences. The noble hierarchy was dominated by a small number of wealthy aristocrats, the grandees, who derived their income from vast estates, situated primarily in central and southern Spain. Below them stood a somewhat larger but less socially exalted group of uneven economic resources, the titled nobles. At the bottom of the hierarchy came the numerous and heterogeneous body of

miento de la riqueza en Castilla (Madrid, I9I 7); Américo Castro, The Structure of Spanish History, tr. E. King (Princeton, 1954); Claudio Sánchez Albornoz, España: un enigma histórico (2 vols., Buenos Aires, 1956); Alfonso García Valdecasas, El hidalgo y el honor (2nd ed.; Madrid, 1958); María Rosa Lida, La idea de la fama en la edad media castellana (Mexico, I952).

${ }^{1}$ For a general discussion of the development of anti-aristocratic sentiment see Fritz Redlich, "European Aristocracy and Economic Development", in: Explorations in Entrepreneurial History, December 1953, vol. VI, no. 2, p. 79.

${ }^{2}$ Luis Sánchez Agesta, "Feijóo y la crisis del pensamiento político en el siglo XVIII", in: Revista de Estudios Políticos, 1945, vol. V, nos. 22-23, pp. I I 2-1 I 3.

- Eugenio Larruga y Boneta, Memorias políticas y económicas sobre los frutos, comercio, fábricas y minas de España (45 vols.; Madrid, 1787-1800), vol. V, pp. I4-15.

4 "Reflexiones que hicieron los Señores Don Lorenzo Irisarri Presbitero y Don Josef Olmeda y León", in: Memorias de la Sociedad Económica, vol. IV, p. 4.

- Sánchez Agesta, "Feijóo y la crisis del pensamiento político", pp. I I 2-I I3. 
hidalgos who made up the majority of the noble population. The distinctive nature of the wars of reconquest against the Moors led to the concentration of the hidalgo population in the north, primarily in Asturias, Guipúzcoa and Vizcaya. It was less numerous but not insignificant in Old and New Castile. In the south, the preserve of the aristocracy and the great military orders, it was very slight numerically. Some hidalgos managed to prosper through membership in the wealthy military orders and through the service of the state. The vast majority, however, were without economic resources. Hidalgos continued to enjoy certain privileges, largely honorific by the eighteenth century, although in some areas the hidalgo population retained considerable local influence through the hereditary possession of the offices of municipal government. ${ }^{1}$

The royal administration wished to persuade the nobility to take an active economic role on two levels. It hoped to induce wealthy nobles to invest in commercial and industrial enterprises, and it desired to persuade poor hidalgos to abandon their prejudices against the industrial arts. The first of these objectives was more possible of realization than the second. Despite the fulminations hurled against nobles for refusing to contribute with their wealth to the encouragement of industry and commerce, the record of the nobility was not as black as its severest critics maintained. Konetzke has stressed the contribution of the Castilian nobility to economic life during the middle ages; Dominguez Ortiz has done the same for sixteenthcentury Seville. ${ }^{2}$ It should be noted also that prejudices against participation in commerce and industry were strongest in Castille, where the social dominance of aristocrats and hidalgos was particularly well established. In Catalonia, the situation was different. The disintegration of Catalan feudalism, similar in structure to the French rather than to the Castilian, combined with geographic and economic factors favorable to commercial development led to the emergence of the strong bourgeoisie lacking in Castile. Although the values of the nobility did not disappear, the successful merchant was not excluded by reason of his profession from at least some degree of social acceptance. This respectability was institutionalized in both Catalonia and Valencia by an influential class, the ciudadanos bonrados,

${ }^{1}$ G. Desdevises du Dézert, L'Espagne de l'Ancien Régime (3 vols.; Paris, r897-1904), vol. I, pp. I 2 I-1 25 ; Vicente Palacio Atard, Fin de la sociedad española del antiguo régimen (Madrid, 1952), Pp. IO-II. In 1787 there were II9 grandees and 535 titled nobles.

2 Richard Konetzke, "Entrepreneurial Activities of Spanish and Portuguese Noblemen in Medieval Times", in: Explorations in Entrepreneurial History, 1953, vol. VI, pp. 115 I 20. Antonio Dominguez Ortiz, Orto y ocaso de Sevilla (Seville, I946), Pp. 5 I- 52. 
who stood between the nobility and the bourgeoisie. ${ }^{1}$ In the Basque Provinces, mercantile activity was also regarded as socially acceptable, even for hidalgos, who made up most of the area's population. The absence of a landed aristocracy, the influence of a long commercial tradition and the peculiar evolution of Basque society combined with economic factors to develop a prosperous merchant class composed largely of hidalgos. ${ }^{2}$

The basis for the crown's campaign against noble prejudices was established by Charles II in a pragmática of 1682 which granted nobles who engaged in commerce or established manufactures a legal guarantee that their status would be respected. Nobles who worked "with their own persons" in manufactures, however, were excluded from the scope of the decree. ${ }^{3}$ The pragmatica of 1682 destroyed whatever legal obstacles had existed against the participation of the nobility in economic enterprises of a certain level. In one form or another, it was reconfirmed several times during the eighteenth century. Philip V confirmed it in $1705 .{ }^{4}$ Provisions guaranteeing noble investors their status were written into the royal charters granted to several joint stock companies organized during the century. The charter establishing the Company of Burgos in $17^{6} 7$ stated explicitly, for example, that investment in the company could never serve as an "obstacle to nobility". 5

Throughout the eighteenth century there are examples of nobles who participated actively in commerce and industry. At the beginning of the century, the Count of Fernán Núñez, a wealthy and distinguished member of the aristocracy, established a textile manufacture on his estates in Andalucia and imported English workers to staff it. Not long afterward, the Marquis of Ariza, of an equally illustrious family, asked the permission of the Council of Castile to construct a paper mill. During the same period, two other well known aristocrats established manufactures; the Count of Aguilar a manufacture of taffetas and

\footnotetext{
1 Sánchez Albornoz, España: un enigma histórico, Vol. I, p. 688; Antonio Domínguez Ortiz, La sociedad española en el siglo XVIII (Madrid, I955), p. 104. For discussion on the emergence of an economically progressive Catalonia see: C. Pi Sunyer, L'aptitud económica de Catalunya (2 vols.; Barcelona, 1927); J. Vicens Vives, Cataluña en el siglo XIX (Madrid, 1961); P. Vilar, La Catalogne dans l'Espagne moderne (3 vols.; Paris, 1962).

2 Julio Caro Baroja, Los vascos (Madrid, 1958), p. 253; Mercedes Mauleon Isla, La población de Bilbao en el siglo XVIII (Valladolid, 1961), Pp. 1 52-1 53 ; Francisco Elias Tejada, El Señorio de Vizcaya (Madrid, 1963), p. 230.

s Pragmática, December I 3, 1682. Novísima recopilación, libro VIII, título XXIV, ley I in Códigos Antiguos de España, ed. M. Martínez Alcubilla (2 vols.; Madrid, 1885).

4 Decree, December 4, 1705 . Novísima recopilación, libro VIII, título XXIV, ley III.

5 Consulta, General Junta of Commerce, October 17, 1767. Archivo General de Simancas, Hacienda-Secretaría, leg. 855 . Henceforth referred to as AGS.
} 
stockings in La Rioja and the Duke of Infantado a tapestry works in Pastrana. Perhaps the most successful noble businessman of Philip V's reign was an hidalgo of modest circumstances from Navarra, Juan de Goyeneche, whose enterprises ranged from lumber operations in the Pyrenees to the manufacture of leather goods, hats, glassware and woolens in several towns near Madrid. ${ }^{1}$

During the reigns of Ferdinand VI and Charles III nobles continued to take an active economic role. The names of noble investors are on the rolls of several joint stock companies established during the 1740 's. A tenth of the investors in the Company of Extremadura were titled nobles. Among them were the Duchess of Alba, the Duke of Liria, the Marquis of Ensenada and the Count of Valdeparaiso. The Marquis of Andía owned a flourishing armaments and munitions works at Égui in Navarra. Noble investors comprised an important segment of the investors in the company of commerce organized in $176_{3}$ by the merchant guilds of Madrid. One of the original promoters of a joint stock company formed in Burgos a few years later was the Marquis of Gastañaga. An enterprising hidalgo from Asturias, Antonio Raimundo Ibáñez, after amassing capital from several commercial ventures, established a successful metallurgical works in Sargadelos. The Count of Aranda, grandee, general and royal minister, one of Spain's wealthiest aristocrats, owned a glassware manufacture in Alcora. And one of Charles III's sons, the Infante Don Gabriel, privately financed several mining surveys in La Mancha which resulted in the discovery of iron and coal deposits. ${ }^{2}$

Nobles also contributed to the encouragement of commerce and industry, although less directly, through the publication of works on economic matters and through membership in patriotic societies engaged in projects designed to stimulate economic development.

\footnotetext{
1 Gaspar Naranjo y Romero, Antorcha que alumbra para empezar la restauración económica de España ... Seville, 1703 in Real Academia de Ciencias Morales y Políticas, Papeles Varios, ms. 10536, no. I, ff. 85-86; Consulta, Council of Castile, Archivo Histórico Nacional (henceforth referred to as AHN), Archivo Antiguo del Consejo, leg. 7223. Bernardo Francisco Aznar, Discurso que formó tocante a la Real Hacienda ... (n.p., n.d.), pp. 176-178; "Dn. Francisco Xavier de Goyeneche", in: Real Academia de Historia, Colección Sempere y Guarinos, vol. VI, ff. 79-82.

${ }^{2}$ La Dirección de la R. Comp.a de Comercio y Fábricas de Extremadura de las gananz." desde I de Octre. de 1747 hta. fin de Maio de 1748, July 28, 1749. AGS, HaciendaSecretaria, leg. 852; Memorial of the Marquis of Andía, 1755. AGS, Marina, leg. 678; Eugenio Larruga y Boneta, Historia de la Real y General Junta de Comercio, Moneda y Minas ..., I 2 vols. in ms., I789. Ministerio de Hacienda, vol. IV, pt. II, ff. 80-81; printed circular, Junta General de la Real Compañia de San Carlos de Burgos (Burgos, 1768); J.-E. Casariego, El marqués de Sargadelos (Oviedo, 1950), pp. 47ff.; Ordenes Generales de Rentas in Ministerio de Hacienda, vol. XXVII, f. 165 ; vol. XXVIII, f. 374 ; Larruga, Memorias políticas, vol. XVII, pp. 85-86.
} 
In 1712 , for example, the Duke of Osuna, a distinguished aristocrat, drew up an elaborate plan for the economic reconstruction of the kingdom. ${ }^{1}$ During the reign of Charles III, enlightened nobles frequently attended the sessions of the economic societies which had been founded in nearly a hundred cities and towns to encourage economic progress. ${ }^{2}$

The preceding enumeration, although by no means complete, indicates that the participation of the Spanish nobility in commerce and industry followed the general European pattern. Although there was some investment in textiles during the first part of the century, noble investment was concentrated generally in those heavy industries, metallurgy, mining, paper, glassware, etc. which the nobility was particularly well suited to exploit. Nobles possessed the land containing the necessary raw materials, and they had the substantial capital required to put such large scale enterprises into operation. From the 1740's onward, noble investment in joint stock companies was common. The participation of the nobility in these ventures was not surprising. The establishment and continued success of the companies depended to a considerable degree on their influence at court. They maintained permanent agents in Madrid to look after their interests, and they sought the support of influential patrons in the royal administration. The companies often were established with great fanfare, as members of the royal family ostentatiously subscribed to the first issues of stock. Wealthy nobles who frequented the court and lived in Madrid - and there were many in this category - could not have avoided the pressure generated by the example of the sovereign, the support of the administration and the tempting blandishments of company lobbyists. ${ }^{3}$

Progressive writers interested in economic problems were not unmindful of the contributions made by individual nobles, but most remained convinced that the attitude of the wealthy nobility as a whole had not changed despite heroic efforts to change it. In 1776 a dis-

1 L. Zumalacárregui, "El proyecto del duque de Osuna para la reconstrucción económica de España en el siglo XVIII", in: Anales de Economía, 1947, vol. VII, no. 28, pp. 477-494 2 Jean Sarrailh, tr. A. Alatorre, La España ilustrada de la segunda mitad del siglo XVIII (Mexico, 1957), p. 257.

${ }^{3}$ For a general discussion on noble investment in Europe, see Fritz Redlich, "European Aristocracy and Economic Development", pp. 78-91. For the problem in France, see John E. Sawyer, "Social Structure and Economic Progress: General Propositions and Some French Examples", in: American Economic Review (Papers and Proceedings), May 195x, vol. XLI, no.2, pp. 32I-329; George V. Taylor, "Types of Capitalism in Eighteenth-Century France", in: English Historical Review, July 1964, vol. LXXIX, no. 3 ×2, pp. $495-496$. 
tinguished member of the Royal Economic Society of Madrid lamented: "in vain have the wisest of our kings sought to induce the nobility to commerce ..., since this prejudice (stronger than the kings themselves) has made nobles obstinate in looking upon commerce as some kind of degradation". ${ }^{1}$ Eugenio Larruga directed bitter criticism against nobles who believed that "they would be degraded if they invested their substantial wealth in contributing ... to the encouragement of the arts and useful sciences". ${ }^{2}$

This conclusion must be accepted, although with some reservations. The pressure of the crown and enlightened opinion could not suddenly have transformed the values of a class whose social prestige remained relatively intact within the framework of a traditionally ordered society. Social prestige continued to remain attached to the ownership of land, the profession of arms, the possession of honorific offices and the preservation of code of honor which regarded participation in commerce and industry as socially degrading. This code, of course, could never be universally binding. Wealthy aristocrats like Fernán Núñez, Infantado, Alba and Aranda, whose social standing was unquestioned, could invest in industrial and commercial ventures without losing the esteem of their peers. Wealthy nobles could invest safely in metallurgy, mining, etc. because the intimate connection of such enterprises to the land endowed them with a certain respectability. And the exhortations of the crown doubtless convinced some nobles to contribute to the public felicity. Yet there was no compelling economic or social reason for nobles to abandon the values which social custom and historical tradition had identified with the nobility as a class. It is true that as the eighteenth century progressed the social position of the nobility suffered to a degree. Economic development and the resulting emergence of an increasingly influential bourgeoisie deprived the nobility of the monopoly of economic resources it had held in 1700 . But economic progress, remarkable as it was, neither radically altered the essentially agrarian character of the economy nor destroyed the economic base of the nobility's social dominance. ${ }^{3}$

There were also practical reasons to account for the reluctance of the nobility to invest in commercial and industrial ventures. The possibility of enticing noble capital was never as great as royal administrators and enlightened opinion assumed. Entail immobilized

1 "Memoria del Señor Don Policarpo Sáenz de Tejada Hermoso sobre el comercio", in: Memorias de la Sociedad Económica, vol. II, p. 46.

${ }^{2}$ Larruga, Memorias políticas, vol. V, pp. 14-I 5 .

3 J. Mercader, A. Domínguez Ortiz, "La época del despotismo ilustrado", in: Historia social y económica de España y América, ed. J. Vicens Vives (5 vols.; Barcelona, 19571959), vol. IV, p. 22. 
the apparently impressive resources of many nobles. A general lack of interest in the efficient management of estates further out down the amount of capital potentially available. Most wealthy nobles were absentee landlords who preferred the comforts of urban life to the drudgery of tending to their estates. When capital was available, it often was squandered on the vain display judged befitting to those of exalted social rank. During the eighteenth century, the Spanish aristocracy retained the reputation for extravagant expenditure which it had earned in earlier centuries. ${ }^{1}$ The prosperity which Spain came to enjoy during the eighteenth century, particularly in the years after 1760 , encouraged investment, but business failures remained common. Even more significantly, steadily rising land values guaranteed the security of landed wealth in a way that industrial and commercial investment could not. ${ }^{2}$

Ambitious hidalgos might have been expected to improve their economic position by seeking riches through commercial and industrial enterprise. To some extent this occurred in the Basque Provinces where conditions made it possible, although even there the hidalgomerchants of Bilbao were second to none in their quest for honors and the vast majority of the hidalgo population remained tied to traditional ways. ${ }^{3}$ In Castile also, there were examples of hidalgos of modest circumstances who became successful businessmen. But for the enterprising hidalgo, there existed a more certain and attractive road to prestige and wealth - service in the administration of the state. The crown traditionally recruited its officials among hidalgos rather than from the aristocracy. The hidalgo fortunate enough to reach the highest levels of the administration could expect generous rewards: a comfortable income, numerous privileges and perhaps a title. It is true, of course, that royal officials at every level of the administration took an interest in economic problems and in this sense contributed to economic development. This contribution, however, was based on knowledge acquired at the ministerial desk rather than from practical experience.

The crown was less successful in inducing poor hidalgos to abandon their prejudices against manual labor performed in an industrial context than it was in persuading the nobility to invest in commerce and industry. There were a number of cases during the eighteenth century of hidalgos who worked at industrial occupations, but those who accepted such employment did so out of desperation rather than

1 Domínguez Ortiz, La sociedad española, Pp. 89-91.

2 For a discussion of the land boom of the eighteenth century see, Richard Herr, The Eighteenth-Century Revolution in Spain (Princeton, 1958), pp. $86 \mathrm{ff}$.

3 Caro Baroja, Los vascos, p. 253. 
through a new found spirit of industry. ${ }^{1}$ Under the influence of enlightened opinion and the benefits of economic prosperity, hostility against participation in commerce and industry declined in the kingdom's urban centers. The same cannot be said for the nation's small towns and villages where traditional values were most strongly held.

One eighteenth-century writer dismissed the fear of hidalgos that they would endanger their status by accepting industrial employment as nothing more than "a mere apprehension of fantasy". ${ }^{2}$ But their concern was by no means unjustified. The noble who engaged in the occupations of tailor, carpenter, blacksmith and in "other low and abject trades" faced the legal possibility of losing his prerogatives until the $1770^{\circ}$ 's. $^{3}$ Charles II's pragmática of ${ }^{1682}$, it will be recalled, had specifically excluded nobles who worked "with their own persons" in manufactures. In 1737 , to cite a specific case, the hidalgos of the district of Montaña de Santander imperiled their status by exercising "oficios mecánicos". ${ }^{4}$ A more serious cause of preoccupation was the policy of successive eighteenth-century monarchs of trying to reduce the number of hidalgos. Poor hidalgos in areas with large noble populations were most directly threatened by this policy. ${ }^{5}$ Hidalgos who saw their status endangered doubtless clung more tenaciously to a system of values which custom and tradition had identified with bidalguia as a means of defence against the pressure being exerted by the crown.

The tenacity with which hidalgos remained attached to traditional values was evident in a long and bitter dispute which took place between the crown and the hidalgo populations of La Cavada and Liérganes, two small towns situated between Bilbao and Santander. The point at issue was the presence in both towns of Flemish workmen brought in to staff a small armaments and munitions works established there at the end of the seventeenth century. Scarcely had the first workers arrived when they began to feel the contempt of the local hidalgos who were numerous and, more significantly, in control of the municipal government. ${ }^{6}$ The harassment to which the Flemish

"Marquis of Saltillo, "La nobleza española en el siglo XVIII", in: Revista de Archivos Bibliotecas y Museos, I954, vol. LX, p. 418; Mario García-Oliva, "Oficios mecánicos en la nobleza montañesa", in: Hidalguia, May-June I96r, vol. IX, no. 46, p. 299.

2 Miguel Zavala y Auñón, Representación al Rey N. Señor D. Phelipe V. ... dirigida al más seguro aumento del real erario ... (Madrid, 1732), pp. 222-223.

${ }^{3}$ Novísima recopilación, libro VIII, título XXIII, ley VIII, nota 5.

4 Domínguez Ortiz, La sociedad española, pp. 98-99.

Ibid., pp. 83-88.

- A royal cédula of 1718 complained of "the ill treatment and extortions", to which the workers had been subject by the local population. AGS, Marina, leg. 676 . 
were subject finally forced Philip $\mathrm{V}$ to take the unusual step of granting them the status of hidalgos - a measure which in theory should have provided the workers with legal protection against vexation by their neighbors. From the time the original grant of bidalguia was made in 1712 , however, until the conflict petered out still unresolved in the 1760's, the local population steadfastly refused to recognize the privileged status which the crown had bestowed upon the workers, as the municipal government seized every opportuninity to harass and humiliate the unfortunate Flemish and their descendants. ${ }^{1}$

The struggle reached its most acute phase during the 1750's when the descendants of the original workers sent an anguished appeal to the Council of Castile complaining that they had been reduced to a "class of inferiority" by the actions of the local government. ${ }^{2}$ In a series of petitions sent to Madrid, the hidalgos retorted with the pride and arrogance of a class convinced of its moral superiority. They boldly challenged the right of the crown to confer bidalguia upon anyone who was not entitled to it by blood. They resolutely affirmed the incompatibility of manual labor and hidalgo status. And they protested with moral indignation against the actions of the royal administration on behalf of the workers:

"It is not believable of the royal benignity of the King that he would wish to cause such affliction to such noble and loyal people and vassals as those of this junta, who always have aspired to the best service of Your Majesty, without their poverty ... having to yield in this aspiration ... to the most opulent and extended province.... Those who are replying desire to conserve pure the lustre and nobility of their houses, which are and have been ... such seminaries of soldiers, ministers and vassals of Your Majesty". ${ }^{3}$

These protests were ignored by the crown which consistently defended the cause of the workers to the point of levying fines and imposing prison sentences on recalcitrant members of the municipal government. But royal pressure on the hidalgos of $\mathrm{La}$ Cavada and Liérganes was unavailing. The local population was as defiant in 1762 as it had

\footnotetext{
1 The course of the struggle to 1755 is recounted in a report prepared for the secretary of state for war, Sebastián de Eslava, March 12, 175s. Ibid., leg. 678.

2 Memorial of the workers, 1755 . Ibid.

${ }^{3}$ Memorial of the municipal government of the Junta of Cudeyo, 1755. Ibid. La Cavada and Lierganes were part of the same unit of local government, known as a junta in this area.
} 
been in 1712 . The conflict finally petered out in the 1760 's, not because the hidalgos had experienced a change of heart but because the muntions works came under direct royal control for the first time in 1763 . The immediate presence of royal officials after this date dictated more discrete behavior on the part of the local residents. ${ }^{1}$

Action to protect hidalgos who worked at manual trades was not taken until the reign of Charles III. Enlightened opinion denounced the restrictive provisions of the pragmatica of 1682 . The Royal Economic Society of Madrid declared that the decree had aided the owners of manufactures but had done nothing for those who worked in them, "as if it were possible to realize anything without limbs". ${ }^{2}$ In $177^{\circ}$ and 1773 Charles III issued orders which finally voided the restriction imposed by the earlier decree. He completed the task with a cédula of March 18,1783 which declared that the exercise of manual trades was not prejudicial to the preservation of noble status. ${ }^{3}$

There is no evidence to indicate that royal legislation and the pressure of enlightened opinion changed the traditional aversion of the hidalgo for manual labor performed in an industrial context. The Basque Provinces excepted, hidalgos on the whole lived in areas which were intellectually isolated and economically backward. Opportunities for secure and profitable employment were few. Hidalgos, of course, could have taken up the manual trades found in every town, but these occupations were not particularly lucrative, and they were professions which tradition and social custom had labeled as dishonorable. The social and legal inferiority of those working at industrial occupations was institutionalized by their exclusion from the offices of municipal government in many towns. The hidalgos of La Cavada and Liérganes, for example, refused to recognize the status conferred upon the workers because such a grant made the latter eligible to hold municipal office. The hostility of hidalgos toward the manual trades was not only a defence of a code of honor consecrated by custom and tradition; it was also a defence of a monopoly of political power at the local level.

II

The prestige which noble status still conferred within Spanish society led the crown to hold out the lure of nobility as a means of

1 The transfer of ownership took place by royal order of November 4, 1763. Ibid., leg. 680 .

2 Memorial of the Royal Economic Society of Madrid to the Council of Castile, December I, 1778. AHN, Consejos, leg. 1240, exp. 2, f. 28.

3 The royal orders of 1770 and 1773 are noted in a consulta of the Council of Castile, February 5, 1783. AHN, Consejos, leg. 853, f. 33; cédula, March 18, 1783 in Novísima recopilación, libro VIII, título XXIII, ley VIII. 
inducing enterprising commoners to establish manufactures and engage in commercial ventures. Several eighteenth-century writers advocated the ennobling of manufacturers. ${ }^{1}$ Gerónimo de Uztáriz, the most important mercantilist writer of Philip V's reign, extolled the example of Louis XIV for having ennobled Nicolas Cadeau and Joseph Vanrobais who had established woolen manufactures in Abbeville. ${ }^{2}$ Later, two master clockmakers, writing to the Royal Economic Society of Madrid, urged the ennobling of manufacturers as "the only way of reaching the heart of man". The Count of Campomanes also evoked the example of France when he noted that bestowal of membership in the order of St. Michael on manufacturers and skilled artisans had done "much to re-establish the estimation of certain industrial arts". ${ }^{3}$

The practice of granting noble status to those who had established manufactures was already established by the beginning of the eightteenth century. During the reign of Charles II requests for noble status from manufacturers were not unusual. In $168 \mathrm{~s}$, for example, the Junta of Commerce vigorously supported Julio Bamfi, who had established a small metallurgical works, in his quest for a place in a noble military order. 4 Six years later, the Junta acted with equal enthusiasm on behalf of Diego Gallego and Miguel de Beraza, two residents of Córdoba, who had requested places in a military order as a reward for having established a textile manufacture. ${ }^{5}$

The accession of the Bourbons did not change this policy. Philip V conceded membership in the military order of Calatrava to Joseph Aguado y Correa, a prosperous man of affairs who had made a fortune as a supplier of provisions to the army during the War of the Succession and then went on to establish a manufacture of woolens in Valdemoro. ${ }^{6}$ In 1736 , a royal provision of bidalguia was granted to Pedro Tomé González of Burgos, a wool merchant who also established several commercial and industrial enterprises. ${ }^{7}$ During the reign

\footnotetext{
${ }_{1}^{1}$ The term, fabricante, which I have translated as "manufacturer", theoretically applied to all engaged in industry, regardless of function. Frequently, 't referred to the owners of industrial establishments, although usage did not distinguish among different types of manufacturers. It is in this latter sense that I have used the term.

2 Gerónimo de Uztáriz, Theórica y práctica de comercio y de marina ( 3 rd ed.: Madrid, I 757 ), p. 54 .

3 "Memoria de los Señores Don Felipe y Don Pedro Charost", in: Memorias de la Sociedad Económica, vol. IV,p.4; Campomanes, Discurso sobre la educación popular, p. 3 ro. 4 Larruga, Historia de la Real y General Junta, vol. IV, pt. I, ff. 338-339.

5 Marginal note of the Junta of Commerce on the memorial of Gallego y Beraza, February 7. 1691. AHN, Consejos, Archivo Antiguo del Consejo, leg. 7223.

6 Larruga, Memorias políticas, vol. IX, pp. 145, I6I.

7 Ismael García Ramela, "Los Tomé-antecedentes familiares-actividades industriales", in:
} 
of Charles III there were similar cases. A wool merchant of Segovia, Laureano Ortiz de Paz, received a grant of bidalguia for having invested more than 2,000,000 reals in a manufacture of fine woolens. ${ }^{1}$ Another beneficiary of royal favor was a silk manufacturer of Granada, Francisco Morales. ${ }^{2}$

Concessions of noble status to promote industry and commerce were not unusual during the eighteenth century, but the crown did not ennoble on a large scale for this purpose. The royal administration realized that an excessive number of concessions would dilute the value of ennobling for those aspiring to enter the ranks of the nobility. The Count of Campomanes warned that concessions of nobility must be made "with the parsimony which is necessary lest honors be made common".3 The crown sometimes attached conditions to grants of noble status. The workers in the munitions works of $\mathrm{La}$ Cavada and Liérganes were threatened with immediate loss of bidalguia the moment they abandoned the works for some other employment. Miguel de Múzquiz, minister of finances during much of the reign of Charles III, deferred approving a grant of noble status to Jean-Baptiste Phelipot, director of the royal manufacture of silks in Valencia, until he had ascertained whether Phelipot had met all the conditions "for which a cédula of nobility was offered him".

There was always the danger that recently ennobled businessmen and manufacturers would abandon their enterprises to imitate the idleness of so many members of the aristocracy. A distinguished member of the Royal Economic Society of Madrid complained in 1776 that many businessmen believed it necessary "to renounce their professions" in order to merit honorific distinctions. ${ }^{5}$ Although it was not easy for a middle-class man of wealth and ambition to acquire nobility on his own initiative, it was possible given the expenditure of the time and money necessary to engage pliant genealogists and to sustain litigation in the courts. A French diplomat in Madrid during the reign of Charles III, Jean François Bourgoing, observed that places in the noble military orders were distributed with incredible laxity despite the exhaustive proofs of noble status which were

Boletín de la Comisión Provincial de Monumentos Históticos y Artísticos de Burgos, r939, vol. XVIII, no. 66, pp. 196-199.

${ }^{1}$ Larruga, Memorias políticas, vol. XII, pp. 286, 302.

2 "Ennoblecimiento por el ejercicio del comercio y de la industria", in: Hidalguía, May-

June $196 \mathrm{I}$, vol. IX, no. 46, p. 296.

3 Campomanes, Discurso sobre la educación popular, p. 3 Io.

4 Marginal note of Múzquiz on the memorial of Phelipot, 1770. AGS, Hacienda-Secretaría, leg. 789 .

5 "Memoria del Señor Don Policarpo Sáenz de Tejada Hermoso sobre el comercio", in: Memorias de la Sociedad Económica, vol. II, p. 46. 
theoretically required. ${ }^{1}$ It was also possible for the aspiring bourgeoisie to acquire noble titles through purchase. The crown often granted hard-pressed nobles with several titles the right to dispose of one or several of them in exchange for adequate compensation. The purchaser had to prove noble status, but a middle class man of wealth and standing could usually amass enough "evidence" to obtain legal recognition of his title. In $\mathrm{I}_{742}$, for example, the Marquis of Santa Cruz received permission from Philip V to dispose of one of his titles, "in order to permit him to repair his estates ... and to educate his sons in such a manner that they can be useful to my service". ${ }^{2}$ The title was eventually purchased by a wealthy merchant of Bilbao, Beltran Douat, who finally secured recognition of his title after sustaining long litigation in the courts. ${ }^{3}$

The aspiring bourgeois continued to be subject to the pressures present in a society in which the nobility continued to enjoy great prestige. These pressures were offset to some extent, however, by a number of factors which allowed a middle-class man of talent and means to acquire a respectable place within society without being a noble. The economic resurgence which Spain experienced during the eighteenth century, particularly during the reign of Charles III, contributed to the development of an influential, if not powerful, merchant and professional class in the kingdom's urban centers. Between 1787 and 1797 the size of the bourgeoisie increased from 310,739 to $533,769.4^{4}$ Merchants who were members of the consulates established in a dozen cities became highly respected residents of their localities. Membership in the Five Great Guilds of Madrid - an institution involved in public and private financial operations at the highest level - was a certain road to social respectability. The bourgeoisie also benefited from the support given by the crown to institutions in which class distinctions played no part. Commoners and nobles sat side by side at the sessions of the economic societies organized during the reign of Charles III. The social respectability slowly

${ }^{1}$ Jean François Bourgoing, Tableau de l'Espagne moderne (2nd ed.; 3 vols.; Paris, 1797), vol. I, Pp. I66-x 70 .

2 Marquis of Saltillo, Un comerciante bilbaino del siglo XVIII: el marqués de la Colonilla (1742-1816) (Madrid, 1932), pp. 15-18, 49.

3 Ibid.

- Palacio Atard, Fin de la sociedad española, p. I I. For the development of the bourgeoisie see Vicente Rodríguez Casado, "La revolución burguesa del siglo XVIII", in: Arbor, I95 1, vol. LXI, pp. 5-29; Juan Miguel Herrero, "Notas sobre la ideologia del burgués español del siglo XVIII", in: Anuario de Estudios Americanos, 1952, vol. IX, Pp. 297-326. Jaime Vicens Vives, "Coyuntura económica y reformismo burgués: dos factores en la evolución de la España del antiguo régimen", in: Estudios de Historia Moderna, 1954, vol. IV, pp. 349-39x. 
being attained by the bourgeoisie toward the end of the eighteenth century, of course, was not due to the acceptance of the nobility. It represented the gradual development of a new pattern of society in which social position was determined by criteria different from those on which the traditional social order was based.

\section{III}

The concern of the royal administration with the attitude of the nobility and its interest in an emerging middle class did not lead to the neglect of what was regarded as an equally serious problem - the hostility of the lower classes toward manual labor performed in an industrial context. Throughout the century the government received complaints that economic progress was being held back by the unwillingness of the populace to accept industrial employment. In I719, for example, the residents of the city of Guadalajara scornfully refused to work in a newly established manufacture of woolens because "they feared the dishonor of being manufacturers of wool". 1 Similar complaints were heard sixty years later. A group of merchants complained to Charles III that in their city there were "entire families who did not engage in any trade because they considered it more honorable to live ... in absolute misery ... rather than suffer the mark of contempt with which our provinces consider every manual trade". ${ }^{2}$ These lamentations were true insofar as they reflected the pervasive influence of traditional social values. They were not, however, universally applicable. Disdain for industrial employment was less noticeable in the areas which experienced rapid economic development. In Catalonia, for example, opportunities for profitable employment combined with economic pressures on the population produced an industrious society which attracted the admiration of visitors to the principality and aroused the envy of the rest of Spain. ${ }^{3}$

As early as 1683 , the crown had begun to initiate measures designed to raise the esteem of manual labor in the eyes of the population through a decree which forbade the confiscation of the looms and

I Antonio Martínez de Murcia, Origen y estado de las Reales Fábricas de Guadalaxara, I 740(?). Biblioteca Nacional, ms. 3300 , ff. 2 10-2 II.

2 Representación hecha por algunos individuos matriculados en el Comercio de Cádiz al Señor Rey Dn. Carlos Tercero, May 19, r779. Biblioteca del Palacio Real, Miscelánea de Ayala, vol. XLIII, f. 289.

3 Jean François Peyron, Nouveau voyage en Espagne fait en 1777 et 1778 (2 vols.; London -Paris, I 782), vol. I, P. 37; Henry Swinburne, Travels through Spain in the years 1775 and 1776 (Dublin, 1779). pp. 389-390; Joseph Townsend, A Journey through Spain in the years 1786 and 1787 (2nd ed.; 3 vols.; London, 1792), vol. I, pp. I I 6ff.; Francisco Rosa y Rosell, Las señales de la felicidad de España (Madrid, 1768), pp. I22-125. 
other tools of the artisans in the silk industry of Granada in punishment for the non-payment of debts. ${ }^{1}$ A century later, the benefits of this decree were extended by Charles III to all engaged in industrial pursuits. ${ }^{2}$ The royal administration also was accustomed to granting manufacturers, artisans and workmen exemption from several onerous obligations such as the quartering of troops and compulsory service in the militia. Practical considerations were behind these measures, but such concessions had the secondary purpose of raising the status of the individuals who received them. Among the privileges of the hidalgo, for example, were freedom from imprisonment for the nonpayment of debts and exemption from service in the ordinary militia. ${ }^{3}$

During the reign of Charles III the crown went beyond these defensive measures and launched an offensive against one of the most powerful instruments of discrimination against those engaged in industry - exclusion from the offices of municipal government, the honorific offices of the republic. This was not a serious problem in the important cities of the kingdom where the immediate presence of royal officials and the existence of guilds and merchant consulates protected the interests of those engaged in commerce and industry. The situation of manufacturers, artisans and workmen in small towns was more exposed. Although the qualifications for admittance to municipal office varied greatly in the different regior $s$ of the kingdom, in many small towns local oligarchies of hidalgos and landowners controlled municipal governments through the hereditary possession of offices and co-optative systems of election. ${ }^{4}$ The crown imposed limitations on the powers of local governments during the eighteenth century, but the latter still possessed certain financial and jurisdictional rights which permitted the harassment of those who were out of favor with the municipal authorities.

By the reign of Charles III, progressive opinion had become loud in its denunciations of the discrimination endured by manufacturers, artisans and workmen at the hands of many local governments. An investigator sent by the Royal Economic Society of Madrid to ascertain the causes of the decline of the woolen industry of the small town of Noves reported that the residents of the town "had abandoned the master manufacturers and workmen completely" and had refused

\footnotetext{
${ }^{1}$ Decree, May 16, 1783 in Larruga, Historia de la Real y General Junta, vol. VIII, f. I04.

${ }^{2}$ Mentioned in consulta, Council of Castile, 1785 (?). AHN, Consejos, leg. 997, exp. 6.

3 Novísima recopilación, libro VI, título VI, ley VII; libro VI, título II, ley II.

4 Antonio Sacristan y Martínez, Municipalidades de Castilla y de León (Madrid, I 877), p. 449; J. Beneyto Pérez, Historia de la administración española e hispanoamericana (Madrid, 1958), pp. 476-479.
} 
to admit them into the municipal government. ${ }^{1}$ The Economic Society of Segovia voiced a similar complaint and urged the royal administration to take immediate action to force the entrance of manufacturers and artisans into local governments. ${ }^{2}$ The Count of Campomanes summed up the views of enlightened opinion when he declared that "admission to the offices of the republic is a justice which should not be refused to those [in the industrial arts]". 3

The royal administration for some time had been compelling municipal governments to admit manufacturers and workmen in certain cases. Contracts between the Junta of Commerce and private individuals for the establishment of new manufactures occasionally contained provisions of this nature. In 1813 an agreement between the Junta and Diego Ramírez de Loaysa declared that the masters, apprentices and workmen in his manufacture were to be eligible to hold municipal office. ${ }^{4}$ It was not until the reign of Charles III, however, that the crown pursued a more aggressive policy. A number of measures were taken to curb the power of the municipal oligarchies. In 1760 the financial affairs of local governments came under the scrutiny of a new royal office, the Contaduría General de Propios y Arbitrios. In 1766 two new positions of a more representative character were established in municipal governments by royal order. Despite these measures, many local administrations continued to discriminate against those engaged in industrial pursuits. The Council of Castile finally instituted legal proceedings against several towns for refusing to admit manufacturers to office. ${ }^{5}$ It should be noted that the crown was not only concerned with raising the status of commerce and industry, it was also interested in undermining the authority of municipal governments. The alienation of local offices through purchase and hereditary possession created serious administrative problems for the royal administration besides acting as an indirect limitation on the power of the monarch.

Although the crown sought to broaden the base of municipal government where manufacturers and artisans were excluded from political power, it frequently encountered the resistance of entrenched interests which were capable of frustrating the progressive measures

${ }^{1}$ Memorial of the Royal Economic Society of Madrid to the Council of Castile, December I, I778. AHN, Consejos, leg. 1240, exp. 2, ff. 25-26.

2 "Extracto de la actas de la Sociedad de Segovia", in: Actas y memorias de la Real Sociedad Económica de los Amigos del País de la provincia de Segovia (4 rols.; Segovia, i 78 5I 793), vol. I, p. I9.

3 Campomanes, Discurso sobre la educación popular, p. ${ }_{36}^{6}$

4 Consulta, Council of Castile, December 29, 1713 . AHN, Consejos, Archivo Antiguo del Consejo, leg. 7223.

${ }^{5}$ Consulta. Council of Castile, February 5, 1783. AHN, Consejos, leg. 853, exp. 8, f. 34 . 
enunciated in Madrid. During the 1780's and I790's, for example, the municipal government of Horche, a small town located near Guadalajara, steadfastly opposed the attempt of the Council of Castile to force the admittance of several small manufacturers of woolens into the local government. The local oligarchy invited the intervention of the royal administration by ordering the enlistment into the militia of several workers employed in the manufactures. ${ }^{1}$ The manufacturers immediately appealed to the Council of Castile and lamented the contempt and disdain with which they were regarded by a majority of the population:

“... for a long time in the ... town of Horche because of a deplorable preoccupation, perhaps too universal in the Kingdom, the important and very useful manufacture ... of ordinary woolens has found itself ill-regarded ..., since the leaders of the town, especially the magistrates, who are from the class working the land, look with a kind of contempt and disdain upon those who dedicate themselves to the commendable object of the manufacture of wool in such a way that not only do they not admit them to the exercise of ordinary jurisdiction, but they persecute them by as many means as their injustice dictates ...; as if industry and agriculture were incompatible, as if both did not contribute to the felicity of peoples, as if the manufacture of woolens had inherent in it some contempt or ignominy."2

The Council reacted immediately to this appeal and sent a special representative to coerce a stubborn municipal government to admit the manufacturers to office. Constant pressure from Madrid finally secured the election of a manufacturer to an important office in 1783 , but the evasions practiced by the municipal electors eventually succeeded in thwarting the intentions of the royal administration. In 1794, thirteen years after the struggle had begun, the local government continued to resist the pressure of the Council of Castile on behalf of the manufacturers. ${ }^{3}$

The situation in Horche has a particular significance because it was one of the factors which led the Council of Castile to propose the most

${ }^{1}$ Memorial of the manufacturers of Horche to the Council of Castile, March 21, $178 \mathrm{r}$. AHN, Consejos, leg. 895, exp. 39, ff. 1-6.

2 Ibid., ff. 7-8.

3 Order of the Council, May 18, 1794 . Ibid., no page number. For a more detailed discussion of the situation in Horche, see W. J. Callahan, "La estimación del trabajo manual en la España del siglo XVII", in: Revista Chilena de Historia y Geografia, 1964, no. 132, pp. $59-72$. 
sweeping measure of the century against popular prejudices - the great cédula of March 18,1783 . An eloquent memorial written by a professor of theology at Santiago, Pedro Antonio Sánchez, also influenced the Council. Using the pen name of Antonio Filántropo, Sánchez delivered a stinging attack upon prevailing prejudices against manual labor. In particular, he lashed out against corporate bodies, including municipal governments, which excluded those engaged in commerce and industry from their ranks:

“... constitutions which terminate only in bestowing honor upon idleness and vice, in denigrating work and virtue, in sowing schism and hatred among the citizens of a state, in maintaining poverty and misery, can they not but be ... opposed to Christian charity, to the legitimate rights of men united in society ...."1

The memorial of Sánchez, together with notes on the crisis in Horche, was remitted to the fiscal of the Council of Castile who shortly reported that legislation on the place of commerce and industry in Spain had often been contradictory "in such a way that the vagabond and the loafer is punished because he does not dedicate himself to work, while the diligent man suffers a more severe penalty which is contempt and dishonor because he is engaged in necessary and useful trades". ${ }^{2}$ The full Council in its recommendation to the king, after noting that admission to municipal offices was being denied to workers "in nearly all the towns of Your Majesty's dominions", urged Charles III to declare a number of manual trades "honest, honored, decent and their professors eligible ... to hold any municipal office". ${ }^{3}$

Acting upon this recommendation, the king issued his celebrated cédula of March 18,1783 which declared that:

"... not only the trade of tanner, but also the other trades and crafts of smith, tailor, shoemaker, carpenter and others of this kind are honest and honorable; the exercise of them does not degrade a family, nor the person who exercises them, nor does it prevent obtaining the municipal offices of the republic ...; nor are the arts and crafts to prejudice the enjoyment and prerogatives of bidalguia ..."4

${ }^{1}$ Memorial of Antonio Filántropo, March 29, I $78 \mathrm{r}$. AHN, Consejos, leg. 853, exp. 8, f. Ir. A printed version may be found in Memorias de la Sociedad Económica, vol. IV, "Memoria I".

2 Opinion of the fiscal, November 8, 1782. Ibid., ff. 22-24.

3 Consulta, Council of Castile, February 5, 1783 . Ibid., f. 32.

4 Novísima recopilación, libro VIII, título XXIII, ley VIII. 
This cédula was the most comprehensive measure enacted by the crown to break down popular prejudices. It did for the population at large what Charles II's pragmática of 1682 had done for the nobility. The importance of the cédula is undeniable, yet it should be remembered that there was little radically new in its provisions. The crown had been employing similar measures for some time; it now generalized what before had been irregular practice. The existence of a long mercantilist tradition, the development of an educated opinion influenced by enlightened ideas and the determination of an enlightened despotism to do what it deemed necessary for the good of the kingdom finally produced the comprehensive measure which had long been in the air.

The basic question remains. To what extent did a change in attitudes take place during the eighteenth century? It has been argued that the cédula of $\mathrm{I}_{78}$ contained revolutionary implications for the future development of Spanish society, and that "'a profound revolution in social values" developed under the influence of an expanding bourgeoisie. ${ }^{1}$ The economic resurgence which Spain experienced during the century and the growth of a middle class lend support to this argument. Yet it is equally true that traditional prejudices remained, as the examples of La Cavada, Liérganes and Horche indicate.

Economic progress, intellectual ferment and government determination to some extent modified the hostility toward commerce and industry inherent in an hierarchically ordered society of the ancien régime. The structure of that society, however, remained intact and served as an obstacle to drastic change. The crown itself followed a cautious policy of avoiding a direct confrontation with traditional prejudices rooted in the very structure of society. To the noble who participated in commerce and industry, the crown offered a guarantee of status. To the aspiring bourgeois, it held out the attractive lure of nobility. And to the ordinary artisan, it offered admission to the honorific offices of the republic. The great cédula of 1783 clearly reveals the dilemma of reformism. Neither in language nor intent did it look forward to the principle of civil equality which soon was to spread over Europe. It sought merely to establish an equality of honor within the narrow limits of an hierarchical society.

1 Antonio Domínguez Ortiz, "Notas sobre la consideración social del trabajo manual y el comercio en el antiguo régimen", in: Revista de Trabajo, I945, p. 680; Luis Sánchez Agesta, "Introducción al pensamiento del despotismo ilustrado", in: Arbor, December I950, p. 366 . 